\title{
Responses to the Economic Crisis among Immigrants in the Czech Republic: Impeding and Inhibiting Factors for Staying
}

\author{
Marketa Rulikova
}

\begin{abstract}
This paper considers the impact of the most recent global economic crisis on immigration in the Czech Republic. Developments during this economically troubled period suggest that the "immigration-inexperienced" Czech Republic, which has attracted significant numbers of people seeking economic opportunities in the past decade for the first time, has repeated historical mistakes made by Western European countries during the 1970 s oil crisis. Initially, promising economic growth at the beginning of the decade allowed the Czech government to ignore issues of immigration, including controlling inflow and immigrants' integration into the majority of society. The sudden reality of jobs disappearing in late 2008 , irrespective of the fact that many employers in the economic sectors are dependent on foreign guest workers, caught the country unprepared. In an effort to level the unemployment rate and dampen societal unrest, the Czech Republic offered financial assistance to immigrants who opted to depart voluntarily, but officials overestimated the willingness of foreign labourers to return home, even if gainful work vanished.

This paper is based on research conducted among participants of the government-assisted Voluntary Return Programme and a follow-up ethnographic study in the Vietnamese, Ukrainian and Mongolian communities in Prague. It can be shown that most immigrants decided to stay despite extreme declines in their living conditions. While the motivations of immigrants to leave or stay are multifaceted, this paper offers an alternative to the "pull-push" model that takes into consideration economic as well as cultural factors, which both impede and inhibit migrants from returning "home".
\end{abstract}

Keywords: Global economic crisis - Immigration policy · Voluntary return programme $\cdot$ Return migration $\cdot$ The Czech Republic 


\section{Introduction}

The present article examines how immigration to the Czech Republic has been affected by the recent global economic crisis, which effectively hit the country in the autumn of 2008. This inquiry is particularly pertinent, since this post-socialist country is relatively inexperienced with immigration, and until the recent crisis, the inflow of guest workers was accompanied by a substantial economic boom in the country. The paper opens with a brief overview of the state's immigration policies of the past twenty years since the collapse of the communist regime. It further discusses how the Czech government attempted to solve the mounting crisis-related threat of massive unemployment among immigrants living in the country and especially among guest workers who only recently arrived (most often) from distant countries. Soon after the outburst of the economic crisis, it became clear that foreign guest workers would be adversely affected to a disproportionate degree compared to the domestic labour force, since the former constitute a significant percentage among manual workers in the depressed export-oriented manufacturing sector. This partly resulted from the fact that it was legally easier for employers to dismiss temporary workers and foreigners. One of the immediate interventions of the Czech government was the introduction of the Voluntary Return Programme (VRP), a practice that was reminiscent of Western European reactions to the 1974-5 oil crisis, where several countries tried to reduce the size of their "temporary-but-not-so-much" immigrant population. ${ }^{1}$ In many respects, the Czech Republic followed the historical trend of destination countries ridding themselves of previously welcomed immigrants and guest workers when economic opportunities in their domestic labour market disappeared (see for example, Beets/Willekens 2009; Penninx 1986; Balderrama/Rodriguez 2006; Ngai 2005).

As could be seen both in recent years and in the past, most immigrants opted to stay in the Czech Republic regardless of their severely deteriorated living and working conditions and the government's attempt to assist them with their return. Earlier studies on the impact of the current global economic recession on migration patterns have suggested that population mobility worldwide, at least temporarily, slowed down in 2008 and 2009 and simultaneously no significant returns of immigrants have been noted in any region (Papademetriou/Terrazas 2009; Wilson 2009). Stagnation in population movement in any direction is also reminiscent of developments in the times of previous economic turmoil, e.g. during the economic crisis of the Great Depression in 1930's, the oil crisis of 1974-5 or the two world wars (Cast/es/Miller 2003). In this light, the findings presented below continue to develop research questions related to migratory trends during periods of worldwide economic recession. They also attempt to put in context the newly achieved status of the Czech Republic among countries that receive immigration rather than being a country of population outflow.

1 The Netherlands introduced its version of a voluntary return programme in 1974, France in 1977, and Germany in 1983 (Sward 2009). 
In the second part of the paper, the reasons behind immigrants' decisions to stay in the Czech Republic despite job losses, exploitation by employers and work agencies and the threat of potential deportation accompanied by a long-term ban on re-entry are examined. By focusing on this issue, the paper contributes to the extensive literature on migrants' decision-making processes about whether to stay in a host country or return. Various theoretical approaches have attempted to explicate what is behind migrants' decisions to settle, return or continue their lives as sojourners circulating between origin and destination countries (Morawska 1991; Cassarino 2004). The richness of this literature, which has dramatically expanded since the 1980s, reflects a diversification in types of migrants.

Researchers of return migration draw on major migration theories in order to explain reverse movements. Whereas neoclassical economists, who emphasize personal economic and social advancement behind migration, view returns as evidence of failure to succeed in the destination country, structuralists argue that returns are correlated with improved economic or political conditions in the home country (Cassarino 2004). The globally interrelated economy thus explains the relatively weak (even if not insignificant) trend of return migration. Balaz and his team (2004) contend that the decision to settle is highly correlated with the variable of the immigrant's country of origin, whether an individual comes from a developed or less developed country. Thus, while most migrants from developed countries travel or migrate temporarily for life- or professional experience and tend to ultimately return home; migrants from less developed countries see their "opportunity differential" - to use the terminology of Papademetriou/Terrazas (2009) - differently. In contradiction to neoclassical economics, the new economic approach argues that remigration can be attributed to the success story when migrants meet their initially identified goals (of earning money, attaining education) and return home. Other researchers draw attention to non-economic motivations behind migrants' returns. Personal reasons might include "nostalgia for home" or disenchantment with the fact that the destination country has not lived up to the image the migrant had before departure (Brettell 1979; Stark/Taylor 1989; Gmelch 1992; Aranda 2006, etc.). A growing volume of research also demonstrates that the ever-stronger transnational ties, which migrants cultivate with their home country, facilitate (and prepare better for) returns (Portes 1999; Morawska 1991; Foner 2005). The current paper expands the idea of return migration by contextualizing migrants' decision-making when experiencing extreme shifts in overall circumstances: From the structuralist point of view, times of economic recession disrupt migrants' "opportunity differential" in a way that both sending and receiving countries seem to be pushing out migrants.

\section{Method}

This paper draws on research conducted in a variety of settings. While trying to gauge the effect of the economic crisis, that began in 2008, on immigrants in the Czech Republic, I decided to focus part of my research on the Czech government's Voluntary Return Programme. The backstage preparations for this programme, not 
only its drafting and execution, but also problems encountered in its implementation, were revealed to me by several officials from the Czech Ministry of the Interior in the process of in-depth and follow-up interviews. During the intensive period of data collection (February - June 2009), I regularly visited the departure centre in Velké Prílepy, a former asylum-seekers facility strategically located close to the Prague airport at Ruzyně. There, I conducted semi-structured open-question interviews with twenty-one departing migrants. These interviews took on average twenty minutes, but individual interviews ranged from 12 to 45 minutes in length, depending on the attitude of informants towards research objectives, and perhaps also the amount of trust that I gained from some persons. All interviews were recorded. I also participated in several organisational sessions, where departing immigrants were informed about details of their journey, their legal rights and obligations under the Voluntary Return Programme. At the centre, I had the opportunity to talk to employees, return organisers from the International Organisation for Migration (IOM), who officially partnered with the Czech government, and native speaking interpreters, who provided me with priceless cultural cues to otherwise incomprehensible attitudes and behaviours of the migrants who were the subjects of my research. I took part in one trip to Ruzyně airport and followed a group of Mongolian migrants up to their plane. While I had this immediate exposure to people who decided to return, I also heard from them about friends, family members and acquaintances who decided to stay in the Czech Republic, even if it often meant moving into the sphere of illegality as their legal work disappeared.

Interesting but insufficient information about those who decided to stay eventually brought me into communities of Vietnamese and Mongolians in Prague. For information on (the most numerous) Ukrainian and other post-Soviet national communities, I relied on my informants from these groups and on less systematic but continuous and frequent encounters with representatives of these ethnic groups. I had an opportunity to interview representatives of Vietnamese and Mongolian communities and participate in several of their events. I confirmed my observations with colleagues who study the respective cultures. In spring and summer 2010, I also conducted interviews with social workers and other professionals from the International Organization for Immigration, Charita, Inbaze and Klub $\mathrm{Hanoi}^{2}$ who provide assistance to immigrants and were in the position to reflect on their experiences from the past two years of severe economic downfall and its consequences for immigrants.

2 Charita is a non-governmental organization managed by the Roman Catholic Church, which has been providing social and medical services in the Czech Republic for more than a hundred years. Inbaze Berkat is a civic association established in 2006 and aimed at aiding immigrants in need. Klub Hanoi is a civic platform promoting cultural contacts between the Vietnamese community and the majority Czech population. 


\section{Czech immigration policies in the past twenty years}

It has only been within the last decade that the Czech Republic shifted from being a country of population emigration to being a transitory land for foreigners heading westwards and finally to becoming a destination for various foreigners seeking improved economic opportunities. However, this rapid transformation, inspired by promising economic developments in this post-socialist country since the advent of the new millennium, caught the Czech government (as well as the ethnically homogeneous Czech society) unprepared. They were unsure how to deal with foreign newcomers, many of whom, as it turned out over time, have settled in the country with the intention of staying permanently. ${ }^{3}$ Until the mid-1990s, immigration policies did not constitute a high government priority. The laissez-faire approach, that held sway immediately following the collapse of the socialist government and that allowed almost anyone to enter the territory, might have reflected "the libertarian spirit of the (post) revolutionary era," as Baršová/Barša propose (2005: 221), but the fragmented and short-sighted scope of this policy also gives testimony to the lack of vision in this sphere of policy-making. A more coherent immigration and asylum framework was set up in the Czech Republic as part of the process of preparation for EU membership, since the country had to abide by the EU regulations as defined in acquis communautaire, i.e. in the area of visa and the "Schengen" system. Yet, time pressure for legal implementation of acquis, along with the fact that the post-communist countries seeking EU membership were left with little space for formulating their individual needs in the area of immigration, resulted in an environment of inertia, where migration policies were somewhat "created by themselves" (Drbohlav in Baršová/Barša 2005). More complex and farsighted immigration and integration policies, which would be coordinated across particular ministries, remain mostly underdeveloped or fail to address the actual needs of both immigrants and the majority society (Baršová/Barša 2005; Poradna pro občanství [Citizen Advice Bureau] 2007). A resolute and consistent stance on which immigrants, in what numbers, and under what conditions should be admitted into the country in order to sustain a stable labour market and create a smooth-functioning multicultural society has been missing. Consequently, the decisions of successive governments have only reflected the immediate situation (and mostly the immediate needs of the labour market) and not a far-ranging set of policy considerations.

Thus, the favourable economic environment, enhanced by the country's successful attraction of foreign direct investments in the late 1990s, most of which concentrated on the manufacturing and assembling industries, which offered semior non-skilled low paid jobs that are generally unattractive to the local labour force, compelled the government to develop more or less structured attempts to seek

3 The commentary here is based on the numbers of permanent residence permits that have been issued. It is reasonable to assume that foreigners who attempted to change their status from long-term residence permit (renewable every year) to permanent residence have the intention to stay in the country. 
"guest workers" from abroad. While the government attempted some active recruitment activities abroad ${ }^{4}$ it was largely private worker recruitment agencies that effectively managed to draw thousands of foreigners to Czech companies, along with the natural process of informal recruitment through chain migration.

For sure, the exact impact of work agencies is hard to state with certainty. For example, Rákoczyová et al. (2007) found in their extensive survey among companies employing foreigners that three quarters of these companies have never used services provided by such agencies. However, their study does not reveal the actual number of foreign guest workers who found employment in the remaining quarter of companies through mediation by a work agency. Leaving aside the quantitative impact of work agencies, there is a consensus among academics, governmental officials and NGO personnel about the huge negative role of these agencies in the current unfortunate plight of many cheated guest workers (Drbohlav/Lachmanová 2008; Pechová 2007; Saková/Martínková 2009). Their pseudo-feudal, so-called "client" structure, where job, accommodation and "security" are exchanged for high fees and often accompanied by limitations on freedoms and other forms of explotation, have been extensively described (Černík 2006; Čermáková 2008).

The liberal admission of (the most vulnerable) foreign workers, accelerated by the persistence of under-regulated, profit-seeking private work agencies (Sakovál Martínková 2009) and by the corrupt behaviour among Czech police officials and Czech consulates abroad (Drbohlav/Lachmanová 2008; Nožina 2010), eventually outstretched the needs of the labour market. This unsustainable trend became especially apparent with the onset of the global economic crisis of 2008/2009. The labour bubble, crowded with foreigners who had come to live the "Czech dream", collapsed in a matter of months. Naturally, the slowdown in manufacturing due to shrinking exports since November 2008 hit immigrant workers hard. Although these guest workers hold (or held) permission for residence and work, job opportunities disappeared. In an attempt to help these victims of the short-sighted immigration system, the Czech government resolved to launch a pioneering and in Central Europe unprecedented programme of assisted Voluntary Return, while also suspending the issuance of work permits.

4 Starting in the mid-1990s, some bilateral agreements were signed with traditional labour supplying countries, including the post-Soviet successor states, and also Vietnam, Mongolia and Bulgaria (Malynovska 2008; Kocourek 2008; Mošňjaga/Lupták 2008; Janeba/Jelinkova, unpublished). In 2003, the government expanded its effort to attract more foreign labour by starting the "Project for Active Selection of Skilled Foreign Workers". In 2008, it introduced a system of green cards, a fast-track for distributing long-term work and residence permits for citizens of selected countries who would be directly channeled into the sectors of the economy with the highest demand. These government-initiated recruitment endeavours have brought only moderate success. 


\section{The Czech response to the crisis: the Voluntary Return Programme (VRP)}

In reaction to the worsening of the situation on the job market, which predominantly affected foreign guest workers, the Czech Republic launched its government-assisted programme of Voluntary Return in February 2009. The official justification for establishing the programme (and thus spending tax money in a particularly sensitive time of economic insecurity) focused on security concerns. The government allocated CZK 111 million (approx. 4.5 million $€$ ) to cover immigrants' repatriation costs and grant them a "motivation fee" to encourage their departure. The initial sum of $€ 500$ per adult person and $€ 250$ per child, which was later reduced to $€ 300$ and $€$ 150 respectively, was said to have been allocated to help the returnees re-establish their lives back home. Participants in the programme could benefit from this offer in exchange for turning in their authorised residence and work permits. In a country with almost 438,000 immigrants, ${ }^{5}$ it was safe to assume that tens of thousands were in a vulnerable situation. ${ }^{6}$ The programme was initially designed for only 2,000 legal immigrants, with a conditional assumption that the programme would be expanded in case of a positive response. This promise was fulfilled in July 2009, when the programme was extended to another 4,000 immigrants and was accompanied by a programme of benevolent repatriations of unauthorised immigrants. Arguably, this eligibility of modification represented a significant move towards addressing the most vulnerable immigrants: those who had already lost their legal path to employment.

It is hard to assess the number of those who actually resolved to return to their home country among all economically affected immigrants. There are no reliable statistics that would indicate the number of those who have actually left the territory of the Czech Republic. Estimating departures is further distorted by the fact that a significant part of the most numerous ethnic group of immigrants in the Czech Republic - the Ukrainians - practices pendulum migration. Thus, it is expected that these workers, who come to the Czech Republic with tourist visas and find employment mostly in the informal economic sector during their stay, will adjust the length and frequency of their "tourist trips" based on job availability. It is inconclusive, though, whether informal jobs disappear during an economic crisis in the same way

5 The official data as of December 31, 2008 (last official data collection before the VRP was launched) registered by the Czech Statistical Office (which is informed by the Directory of Czech Alien Police) was 437,565 persons, out of which 405,631 possessed residence permits for 12 months or more. These numbers, however, do not take into account the number of unauthorised immigrants, which is extremely hard to estimate (Czech Statistical Office 2009). The most extreme accounts estimate an additional 300,000 foreigners living in the Czech Republic (Drbohlav 2008).

6 The Czech Ministry of the Interior indicated that the visas of 68,000 immigrants expired in August 2009 (Pecina 2009). Many of these immigrants would not have had their work contracts extended. Not all of these visa holders will get into serious economic problems, but it was reasonable to assume that a substantial number could encounter difficulties surviving under current conditions. 
Fig. 1: Trend in the number of foreigners - monthly data; 2008/09-2009/10
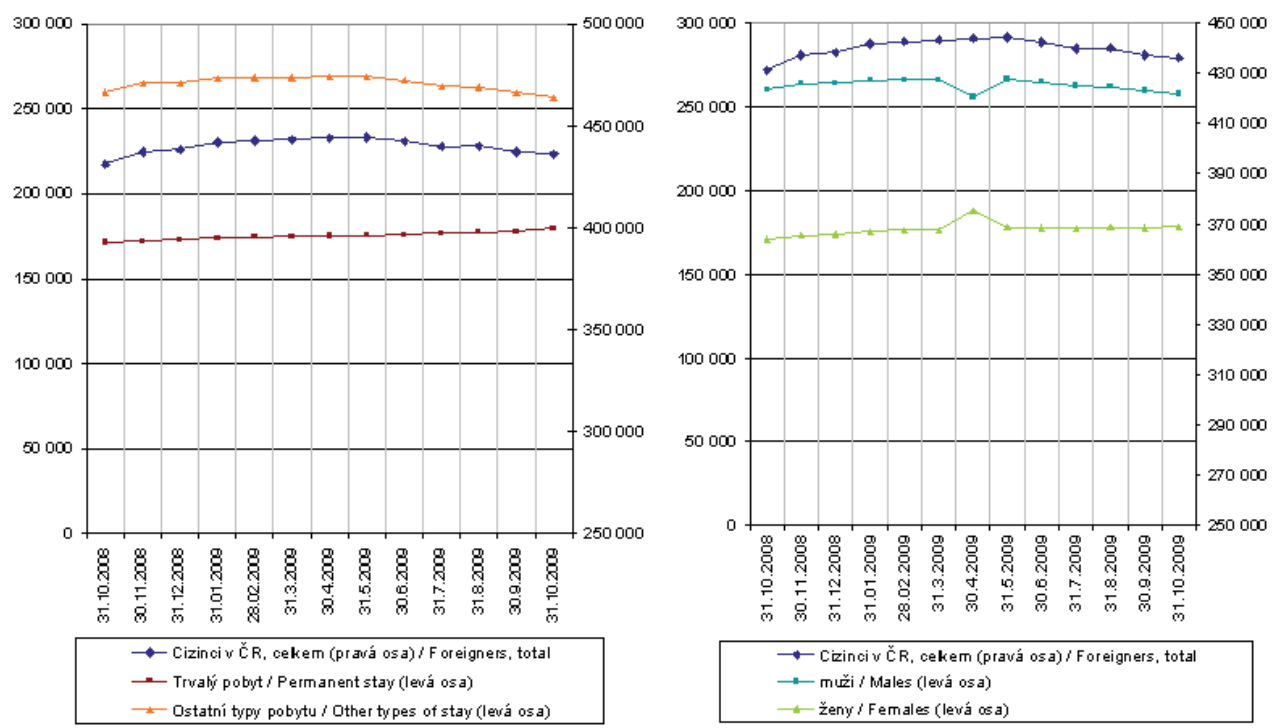

Source: Czech Statistical Office 2010.

and with the same frequency as jobs in the formal sector. Just the opposite might be the case. They might actually be on the rise, given that employers might perceive the commitment to legally well-protected workers too binding and risky.

Yet, a brief look into the data on authorised foreigners residing in the Czech Republic does not reveal any dramatic declines in immigrant numbers (among officially registered immigrants) in the past two years (see Fig. 1).

Additionally, the statistics of the VRP suggest that the programme designers overestimated interest among immigrants in assisted returns. The first phase of Voluntary Return, prepared for 2,000 persons, concluded with 1,781 registered applicants and 1,744 realised repatriations. In the second phase, programme participation dropped enormously: only 218 documented and 169 undocumented foreigners had registered for the next phase of the programme (Ministry of the Interior 2009; for more comprehensive statistics, see table 1). Consequently, the total number of Voluntary Return participants proved to be much lower than the number of those immigrants who decided to stay despite the fact that many had gotten into serious economic difficulties due to unemployment during the recession.

While talking to informants who had decided to take up the unexpected and "generous" (as many perceived) governmental offer, it became clear that they could be roughly divided into two types of cases. The first group included those who encountered serious problems in the Czech Republic, even if not as appalling as cases brought up in the media and other studies, but could not figure any possible remedy. In my sample, practically everybody arrived in the Czech Republic and received a job through an agency. The typical fee for such services ranged between $\$$ 
$700-2,000$ (€500-1500, including plane tickets). Only one informant indicated that he had paid $\$ 12,000(€ 9,000)$ for job mediation. This informant was an untypical case in many respects, as he came from India, a country that generally does not provide labour to the Czech Republic. He came to the Czech Republic through England, where he was recruited by a Ukrainian middleman. While these are significant sums for most economic migrants, they are relatively low compared to the often quoted recruitment fees of $\$ 10,000-13,000(€ 7,500-10,000)$ found among Vietnamese immigrant guest workers (Pechová 2007; Komárek 2009; Krebs 2010). Several of my informants developed major medical problems in physically demanding jobs. Typically, the participants had relatively minimal social ties and only a little or no support group in the Czech Republic. Or alternatively, their entire group was isolated from the majority society, did not have language skills, and seemed to be unable to orient themselves in the host society, its job market and its legal environment. Based on the accounts of several of my informants, these isolated groups of mutually interdependent guest workers (many from Mongolia) who faced similar difficulties departed in large numbers, hundreds participated in the VRP.

The second group of programme beneficiaries, which was smaller in my sample (6 out of 21 informants), included people who were similarly disillusioned, but who wanted to leave the Czech Republic anyway. Typically, they had somewhat clear plans what to do next. In quite a few cases, this plan included another move in search of employment - most commonly to Russia, where (in their words) it was easier to get a job without formal permission. Another popular destination for job migration that became apparent during my interviews was the Republic of Korea. Informants were aware, though, of work permit quotas and difficulties to realise their trip. Thus, participation in the VRP for this second group was a "rational" use of a public allowance, and as such, an unexpected but pleasant "gift". In one or two cases, the eligibility of my informants in the project was highly problematic. For example, one informant from Moldova admitted that $s /$ he was leaving with $€ 2,000$ in savings, which was against the rules of eligibility. Another middle-aged woman, who came to the Czech Republic from Ukraine, admitted that she arrived only after the programme had already been implemented and that participation in the VRP was a backup plan, which was also against the initial idea of the assistance programme:

Initially, I applied for the visa together with my husband. I received it and he didn't...I didn't want to go anywhere...I cried. You know, I never did anything without my husband in my entire life...But the whole family insisted on me going. They told me that the visa cost so much money that I have to take advantage of it...that I shouldn't be worried about anything that I will be living with my cousins. And after all, I can always come back through the programme... When I couldn't find a job after three months, I decided to take up on the opportunity to return through this programme...

When asked about whether they would come back if the labour market situation improved, a third of my informants (7 out of 21) indicated that they would. Some of them added the qualification that they would never come via an agency again. During their stay in the Czech Republic they had come into contact with employers 
or other acquaintances that they could take advantage of when planning a return trip to the country after the crisis is over. So, an identifiable portion of those departing represented well-connected, independent, entrepreneurial workers who could contribute constructively to the Czech economy. In a sense, this would seem to indicate that the self-selection effect of migration, which has been acknowledged in the migration literature (Borjas 1987; Morawska 1991; Chiswick 2000), works in reverse here, by sending home some of the most desirable labourers. Such an observation also suggests that resourcefulness enhances further mobility. This impression then leads to the question whether this generalisation is valid for the entire population of departing immigrants. If so, it would suggest that the host society has to face the harshest consequences of job losses among immigrants because they loose at least a portion of the rather productive immigrants while retaining some of the least productive and most dependent ones.

\section{Consequences of the economic crisis for immigrants in the host country and their coping strategies}

Officially, 53,842 foreigners lost their job in the course of 2009, which means that every eighth foreigner, including professionals and permanent residents of foreign origin (Ministry of Labour and Social Affairs 2009), became unemployed. If one only takes into account guest workers, it appears that between a third and a fourth of those in this category of foreigners lost his or her job.

As narratives of informants in Velké Prílepy suggested and some later studies confirmed (Krebs 2010), significant numbers of recently arrived guest workers were personally hit to a greater or lesser extent by the distorted economic environment in the Czech Republic in 2008-2010. Luckier ones were relocated to jobs with different firms, which were accompanied by lower pay and/or reduction in contract terms (e.g. part-time contracts, short term contracts without benefits, etc.). These practices were known before, but their extent escalated during the period of crisis. Domestic companies became reluctant to commit to costly employment contracts. In addition, work agencies and middlemen reacted to reduced profits from importing foreign labour due to government's decision to freeze work visas by coming up with ways to charge extra or otherwise cheat those guest workers who were already in the country. (One such method was demanding higher charges for assistance with visa adjustments as will become clear below).

Jobless temporary immigrants have to face multiple challenges, some of which are shared by all unemployed individuals, but some of which are specifically attributed to (and complicated by) their uncertain legal status. Most fundamentally, they have to preserve as much of their income as possible in order to survive in the host country, where they typically do not have family to lean on, neither financially nor psychologically. Oftentimes, this coincides with the need to send money back home to support the family (or follow through on investment plans that have been made) and, in case of debts incurred, to pay instalments. The situation is particularly strained, if the debt was advanced from private creditors, who do not hesitate 
to threaten the indebted family with severe penalties or even physical harm if their usurious terms are not met.

Overall, frequent changes of employers and reduced, deferred or never-paid salaries have become a common reality for most guest workers in the Czech Republic in 2009-2010. In some cases, this situation has placed guest workers in a position of near vassal-like dependency on their employers and middlemen. The following narrative seems to represent a very common story among those who recently arrived in the Czech Republic:

...Then they stopped paying me... Actually they gave us a deposit of CZK 2000 a month for food...then I started using my savings...and now I have nothing left...that's why I am leaving. But I will try to get this money back from those bastards, even at the cost of going to the police...They promised to send the money to me in Kazakhstan or to leave it with my brother who came here with me [and is staying] but I am not trusting them...But I will get the money back... (a middle-aged Kazakh man)

During this period of "accepted exploitation", immigrants, mostly Mongolians, Moldovans, Uzbeks and citizens of other CIS countries, exhausted their savings, which represented several years of hard work for many of them. These trapped migrants could not even apply for VRP assistance because formally they were not unemployed and thus did not qualify for participation. (In a few cases, informants in Velké Prílepy revealed that the foreign police officials were flexible and responsive to their plight and incorporated them into the VRP despite formally lacking a termination of employment.) Unemployment among guest workers is precarious due to the fact that, unless they are permanent residents, temporary immigrants do not qualify for unemployment benefits, despite paying taxes.

While many immigrants "found" themselves in dependency as a result of deteriorating relations to employers and middlemen, some others "voluntarily" accepted this status when their previous employment disappeared. In his study of Vietnamese guest workers, Krebs (2010) discovered that some immigrants agreed to work only for food and shelter. While such terms might be intended and interpreted by the employers as generous assistance to fellow countrymen, it is difficult to see it as anything other than labour exploitation. Cases of straightforward human exploitation, i.e. involuntary enforcement of labour, have been recorded as well.

In addition to economic difficulties, guest workers who have opted to remain in the country need to make an additional effort to maintain their legal residence status in order to preserve their chances for re-employment and to avoid deportation. In terms of long-term planning, for some it is crucial to maintain the legal residency in order to be able to apply for permanent residency in the future, which is the basis for an eventual family reunion. In order to retain legal residence permits (which are tied to existing work), jobless guest workers often adjust their status from "employees" to "self-employed entrepreneurs", "members of a limited partnership" or "members of a co-op", even if their actual working position remains dependent or they engage in no gainful activity at all. This practice of legal adjustment is an expensive busi- 
ness, since these business-type visas require additional administration fees (e.g. for obtaining a trade license), more expensive commercial health insurance ${ }^{7}$ and the filing of independent tax returns. Most of these conditions are unfamiliar to the immigrants - which leaves them at the mercy of legal and financial experts. These need to be addressed by middlemen, often foreigners themselves, who profit from their knowledge of the Czech legal system, personal connections and linguistic skills. Similar conditions and practices are valid for student visas. All additional and repetitive costs of "independent" statuses constitute a permanent financial burden, especially given the fact that any work, business and student visas need to be renewed every year. The expression "feeding the papers" has been tailored to those immigrants who are forced to spend a significant proportion or all of their income to assure their continued legal status in the country (Krebs 2010).

\section{State of "stuckness": impeding and inhibiting factors to returns}

As mentioned above, available demographic information indicates that the vast majority of immigrants - including semi-settled immigrants and guest workers who recently arrived - have opted to stay in the Czech Republic despite their shrinking prospects of decent earnings and an improved quality of life in the Czech Republic. Data from the VRP, official statistics on foreign populations, as well as my own inquiries of individual ethnic groups suggest that the degree of remigration is unequally distributed among these separate groups of migrants (see table 1). While proportionately large numbers of Mongolians and Uzbeks were leaving, Vietnamese and Ukrainians were much more reluctant to depart, which can be drawn from a combined statistics showing the total numbers of a given ethnic group and its participants in the VRP.

The most salient variables, which explain the different degrees of readiness to stay or return among different ethnic groups, are addressed below, based on the accounts of informants. They can generally be divided into two categories, namely impeding and inhibiting variables. Impeding factors are usually objective or circumstantial factors that prevent or make it difficult for a migrant to leave, such as the existence or the lack of a supportive community or costs of return (combined with costs of re-entry), debts incurred etc. Inhibiting factors are usually subjective factors, often culturally conditioned, that influence the migrant's willingness to return, such as shame of one's failure to succeed abroad. Situational, often economic variables are more tangible and obvious, and thus dominate the migration literature as major factors of mobility (usually referred to as "pull-push factors"). But the inhibiting, more nuanced and subjectively experienced, culturally-based patterns al-

7 Foreigners on business visas without permanent residency are not allowed to take part in the public system of health care insurance. They have an option to insure themselves privately. This insurance, however, costs more and also does not provide care to the same extent as the public system does (Hnilicová et al. 2010). 
Tab. 1: Voluntary Return Programme

\begin{tabular}{lcccc}
\hline & $\begin{array}{c}\text { Foreigners in } \\
\text { the Czech } \\
\text { Republic } \\
\text { (December } \\
31,2008)\end{array}$ & $\begin{array}{c}\text { Temporary and } \\
\text { long-term } \\
\text { permits + visas } \\
\text { for more than } \\
\text { 90 days } \\
\text { (December 31, } \\
\text { 2008) }\end{array}$ & $\begin{array}{c}\text { Participation in } \\
\text { VRP } \\
\text { (December 15, } \\
\text { 2009) }\end{array}$ & $\begin{array}{c}\text { VRP participants } \\
\text { as \% of } \\
\text { temporary permit } \\
\text { and visa holders } \\
\text { (rounded) }\end{array}$ \\
\hline Total & 437,565 & 265,374 & 2,089 & \\
Ukraine & 131,921 & 91,291 & 60 & $100 \%$ \\
Vietnam & 60,255 & 25,463 & 283 & $0.07 \%$ \\
Moldova & 10,636 & 8,522 & 17 & $1 \%$ \\
Mongolia & 8,569 & 7,104 & 1,342 & $0.2 \%$ \\
Uzbekistan & 2,307 & 2,191 & 314 & $19 \%$ \\
Russia & 27,086 & 15,308 & 8 & $0.05 \%$ \\
\hline
\end{tabular}

Source: Personal calculations based on data from the Czech Statistical Office, 2008 and 2009, and the Czech Ministry of the Interior, 2009.

low explaining seemingly irrational decisions of migrants to remain in a country, where opportunities have disappeared (and thus they also help us to fill a gap in understanding migrants' motives). The research of immigrants indicated that the most salient factors affecting the decision of immigrants whether or not to take advantage of the VRP were the existence of major debt, the existence or the lack of a supportive community and the less tangible factor of significance of migration in particular cultures.

\section{$7 \quad$ Incurred debt}

Despite the presumption that the poorest immigrants might want to leave (and thus would need to be assisted), data suggest an alternative and somewhat complex scenario: It appears that the worse the situation of the migrant, the less likely he or she seems to seek a solution in returning, even when the host government offers financial and logistic assistance for such a return. This is especially the case for heavily indebted guest workers (mostly from Vietnam), as well as for immigrants who are still hoping for salaries to be paid. The decision to stay cannot necessarily be interpreted as a sign of passivity and resignation. Many "captives" of the client system get stuck, because they try to get their salaries which are due and do not want to lose the opportunity to obtain these funds. In my research, this "seeking of justice" seemed to particularly preoccupy immigrants from the CIS countries. This was also the case for people who have borrowed money from their families to pay for their trips, or those who have pledged their savings and houses as security to a 
private creditor or a bank. For those groups, there is no alternative to return home without sufficient resources to pay off their debts. Consequently, for people from countries like Vietnam, where one has to live on several tens of dollars a month, a five hundred euro bill and a plane ticket would do little to provide relief from the debt trap that they would have to face once they have returned home.

Caught between two inauspicious sets of conditions, these guest workers opt for staying in the host country, hoping that the economic situation will eventually revert and that they will be able to stick to the planned schedule on their way to prosperity. In his study of Vietnamese guest workers, Krebs (2010) discovered some cases where indebted families in the home country sent money to support their family members in the Czech Republic. These "converse remittances" are absent in migration literature. They reflect the degree of despair of migrant households in times when sending as well as receiving countries push migrants out. Despair then forces many of these immigrants into illegal employment, slavery-like work environments, and sometimes areas of organised crime (Nožina 2010).

\section{Role of the community and of social networks}

An additional factor that appeared to play a significant role in decision-making among crisis-affected immigrants, whether they should return or stay, was the availability of an ethnic community (or a network) in the host country. A "community" is characterised as an ethnic group whose members share a common cultural and historic heritage. They reside or gather in a specific location, i.e. an urban neighbourhood and organise their social life. A "network" is characterised by a more loose association of individuals - who may or may not know other members of the network - who share some characteristics and interests and who provide each other with emotional support, mutual assistance and information. While their contacts may or may not be intensive, the members of a network do not typically inhabit the same locality, at least not the majority of the members. It can be assumed that the more geographically, logistically or financially distant the home country, the more important become such communities and networks.

It has been well documented that through a variety of institutional means, the community helps its members with finding employment and often provides alternative job opportunities within its own immigrant-supplying (third) sector (Light 1972; Bonacich 1973; Massey et al. 1998). Portes and Bach called the latter ethnic enclave economies (1985). The authors define these as "strong communities" which are not only numerically significant but also include a class of entrepreneurs who create job opportunities for the others (ibid). An ethnic community is also a source of social capital to a migrant: its members share information about legal and social rules and

8 Data on average monthly salary in Vietnam vary. While the usual estimates range between $\$ 30-100$ ( $€ 22$ and 75 ), the official source, Vietnamese Department of Labor, indicates that in early 2010, an average Vietnamese worker earned 150 dollars $(€ 113)$ a month. http://www. presscenter.org.vn/en/content/view/1915/89/ Retrieved: February 7, 2010. 
habits in the host country, and they also offer moral support and other forms of altruistic help to those in need.

In the Czech context, the Vietnamese in particular constitute such a tightly organised and active immigrant community. The most tangible proof of this vibrant Vietnamese community is its business centre, known as Sapa, on the outskirts of Prague. Initially serving as a storage and wholesale site for goods arriving from Asia, Sapa has developed into a thriving market place over the years, which is mainly frequented by the growing Asian population. With the advent of the economic recession of 2008/2009, jobless Vietnamese workers from Prague and elsewhere received free food and shelter at Sapa. Charity was organised around the local temple. According to Mrs. Vu Thi Thu, a Buddhist spiritual leader at Sapa, half a dozen of the members of the local temple prepared over $\mathbf{3 0 0}$ meals every day in May 2009 for their impoverished fellow Vietnamese. Mr. A. Dat, a local entrepreneur, reported that a group of businessmen decided to turn one of their storage spaces into a temporary dormitory for the most desperate homeless Vietnamese. Krebs (2010) estimate that 7,000 unemployed Vietnamese immigrants found haven in Sapa over the most critical winter of 2008/2009.

Ukrainians, who constitute the most numerous ethnic group among immigrants in the Czech Republic and who started arriving in the Czech Republic in the 1990's, have not created a community as tightly linked and physically close as the Vietnamese. Their tendency toward looser social connections and less visible Ukrainian communal life can be explained by a shorter duration and the pendulum character of Ukrainian migration. Moreover, the absence of racial distinctiveness in relation to the Czech host population and the linguistic closeness of the Czech and Ukrainian languages enable the Ukrainians to better integrate into the Czech society. While Ukrainian workers tend to share the accommodation with their ethnic compatriots, they do not concentrate in certain urban neighbourhoods. ${ }^{9}$ Ukrainians in the Czech Republic thus tend to rely more on networks than on a locally defined community. For a Ukrainian, a cell phone or an internet connection represents a link to his or her community instead of a specific part of the city. The occasional expressions of communal life are organised on an appointment basis in popular cafés, restaurants and bars.

While the Vietnamese community and the Ukrainian networks assist their temporarily unemployed countrymen to stay in the Czech Republic, the absence of an "own" solid cultural and ethnic community seems to have led to increased returns among Mongolians or Uzbeks. The Mongolians, in particular, represent a largely detached ethnic group without much social capital, which leaves them with very few opportunities to carry on after they have lost their job. Additionally, their linguistic distinctiveness (relatively few Mongolian guest workers speak Russian, not to men-

9 One of the reasons for the absence of residential communities is the existing regulated housing market in the Czech Republic which limits spatial stratification (Lux et al. 2002). A clear advantage of these policies is a reduced spatial segregation of Czech cities. 
tion the Czech language) does not facilitate using the infrastructure of other ethnic communities nor seeking jobs in Czech businesses on their own.

It needs to be emphasized, though, that the "retaining" effect of ethnic communities may have a negative effect as well. While an ethnic community or a network is commonly viewed as a favourable source of social capital that can serve as safety net in uncertain times, this community assistance is not always offered without reserve (Grzymala-Kazlowska 2005; Nazario 2007; Pai 2008; White/Ryan 2008, etc.). Even if gratuitous patronage for fellow migrants, who often come from the same village, extended family or group of friends, is commonplace, there is also evidence of job mediators or employers who exploit their countrymen. In the Czech Republic, Ukrainian work agents are known for cheating their countrymen and other immigrants and for coercing vulnerable immigrants into paying them money in exchange for promises of employment, visas, accommodation and "security". Mafia-like Vietnamese middleman agencies - so called dich vu - have also been noted (Burčíková 2006; Martínková 2007; Pechová 2007; Nožina 2010; Krebs 2010). Vietnamese entrepreneurs often pay extremely low salaries to their predominantly Vietnamese employees and do not compensate for working under often harsh outdoor conditions. An hourly wage for street trading (in a street kiosk, for example) can be as low as 30-40 CZK (\$2). An anecdotal case of exploitation of countrymen was also recorded in the course of the VRP processing, when a Mongolian interpreter assisted her fellow countrymen with programme applications, but misled them about the size of the allowance and retained the difference.

The vast majority of the interviewees in Velké Prílepy have encountered malfeasance while staying in the Czech Republic; regardless of their country of origin. Most of them reported that Ukrainians had been their "clients", a term applied to individuals by foreigners who would usually be referred to as "middlemen". "The Czechs are all right, they are civil; it's our own people who create problems for us", commented a 45-year-old Uzbek, while his fellow countryman of similar age, whom he met in the camp, nodded. By "our people", both men referred to Ukrainian clients who deprived them of their salaries. "Our" thus did not strictly relate to their fellow countrymen, but to citizens of Ukraine who used to share the common space and culture of the Soviet Union. "Europe is civilised. I like it here. But that post-communist mentality, it is unfortunate", he complained.

According to its officials, the Ministry of the Interior is aware of these mafia-like structures. However, within the current Czech legal framework, police cannot initiate an investigation without receiving an official complaint, and most immigrants remain silent. They are sometimes unaware of their rights, but - based on what I heard from the departing migrants - they commonly do not trust the objectiveness or effectiveness of the Czech investigatory and judiciary systems, or they are afraid of revenge. The afflicted immigrants often do not want to report against "clients" out of fear that they will imperil their fellow immigrants who opt to stay. Thus, even though one of the major sources of foreign labour exploitation is registered, very little is actually done to overcome this unfortunate situation. It also appears that the Ukrainian client system operates internationally: For example, an Indian informant 
came to the Czech Republic through a Ukrainian "middle-woman", who also provides jobs in the UK where she resides.

\section{$9 \quad$ Cultural meaning of foreign migration}

Just like the term "the American Dream" is associated with immigrants' success, today many Vietnamese, Ukrainians, Uzbeks and Mongolians see Europe as a land of opportunity. They are ready to leave their families and go into debt in order to obtain legal employment there or get smuggled in. It did not take long after the accession to the EU that the Czech Republic began to attract serious foreign direct investments and thus became one of these new dream countries. In Vietnam, rumours spread about Việt Kiều millionaires from the Czech Republic spending their holidays in Vietnam. People living in the former Soviet Union vaguely recall that quality products originated in the communist Czechoslovakia, at a time when Soviet goods were uniformly poor in quality. Many of those who decide to seize their chances in the Czech Republic hardly know where it is located on a map. And many who actually arrive know little or nothing about common practices or the economic conditions in that distant country. Nevertheless, they have the goal of working in the host country for several years, remitting their earnings back home, in order to pay back the debts they have incurred. By building a house or investing in a small business, they want to improve the wellbeing of their families before eventually returning.

Depending on the status of the economy in a sending country, families expect the remittance of cash in order to pay back the debt associated with sending the immigrant abroad, to purchase basic necessities, to invest in housing construction or simply - and as numerous studies confirm (Massey et al. 1998) - to engage in ever more sophisticated and expensive consumption. The expectations of families who have been left behind are enormously high. It is well-documented how hard immigrants try to live up to these expectations, sometimes living at the edge of subsistence in order to be able to help their families back home (Ehrenreich/Hochschild 2004; Nazario 2007; Pai 2008, etc.). Similar stories are told by all immigrants from different countries who come to the Czech Republic. Similarly, most of the informants have been sending money home. Some informants revealed that they were trying to finance their children's studies, but in the vast majority of cases, money was spent on everyday consumption (Nguyen 2010). In order to be able to remit money home, they were prepared to reduce their living conditions in the Czech Republic. Many live in overcrowded apartments and others in simple dormitories, of which some are located beyond the limits of the city and require long commutes. Sometimes, shoplifting is a method to send a little present home, when cash is scarce.

A migrant often feels frustrated and ashamed, when he or she fails to contribute the expected financial support. The inability to support their relatives back home and to live up to their expectations is a factor that forces the migrant to stay on and to minimise his or her own expenses. In case of a job loss, desperate migrants are forced to accept any job, even if they are obviously exploited or if the job is illegal. This, on the other hand could get them into trouble with the authorities. Women, 
often single-mothers, who engage in prostitution do so, despite the fact that their reputation back home is at risk, should people discover the nature of their employment (for example from other parts of the world, see Ehrenreich/Hochschild 2007 or Pai 2008).

At the same time, it should be recognised that the meaning of migration varies between different cultures, translating into different "philosophies of life". While exploring this issue among foreigners in the Czech Republic, it was suggested to me that in more sedentary societies, migration represents huge social and economic costs and thus needs to be compensated by tangible gains. In traditionally nomadic societies, migration is treated more routinely, if not fatalistically. Such an argumentation can be supported by the following comment, which was made by a forty-year-old Mongolian returnee who works as computer science professor at Ulaanbaatar University and who took a year off to come and earn some extra money in the Czech Republic: "We should be grateful for having been born in such a beautiful country to return to... And the lost money?... Well...What can you do?... You live on...." This could explain why contemporary Mongolians - whose cultural norms and traditional social structures are organised on the basis of nomadism - treat spatial mobility and travel in pursuit of job opportunities more easily and experimentally, and accept the risks more readily. It seems to be their slogan that just as opportunities come and go, people must pursue them. This admittedly oversimplified picture of Mongolian mentality might, however, represent an additional reason why Mongolians have disproportionately frequently applied for the VRP and why, generally, disproportionately many of them left the country.

\section{Conclusion}

The case study of immigrants in the Czech Republic during the global economic crisis in 2008/2009 confirmed already existing trends in other parts of the world: Namely that immigrants opt to stay in the destination country during hard economic times, because many of them have already resolved to settle down. In this respect, the country seems to resemble other migration receiving states and thus can expect to encounter similar (positive as well as negative) effects associated with the presence of large migrant populations on its territory in the future. While stagnancy rather than decline of the immigrant population could have been expected in 2008/2010, the Czech government attempted to send the most unfortunate crisisaffected guest workers back home by means of the Voluntary Return Programme. While the government justified implementing such measures on the basis of security concerns, the word "return" really seemed to constitute an euphemism for "disposal", since the government essentially hoped to get rid of guest workers who had ceased to fulfil the useful function of cheap labour. The wording "return" also conveys that the place where migrants belong is where they came from and not the place where they currently reside, regardless of the opinion, aspiration or loyalty of the migrants themselves. 
As occurred in Western Europe several decades ago, the Czech VRP despite some initial interest eventually failed. It did not only fail to fill assigned spots for voluntary returnees, but my research found that it also did not attract and assist the departures of the most needy immigrants. Ironically, the most impoverished immigrants were reluctant to accept the one-way plane ticket and a $€ 500$ motivation fee. The puzzle of this seemingly irrational decision has at least partly been disentangled, when we examined some structural circumstances of these people's lives (the impeding factors). The world of poverty, which originally pushed them to the Czech Republic, has been replaced by the world of debt, which is even more debilitating. Multi-thousand-dollar debts accompanied with threats to the wellbeing of family members back home, who are vulnerable to creditors, makes a five-hundred-euro banknote seem like irrelevant pocket money. In addition, inhibiting factors such as the feeling of shame for failing to provide for the family that had put expectation and hope into their journeys, constitute additional reasons why guest workers resist all efforts of encouragement to return home. Despair, increased by impeding and inhibiting factors, forces these migrants to stay, often getting caught in a situation of "stuckness", in which they are neither here nor there, taking up any job or "activity" which promises income or at least survival.

While the humanitarian aspect of the VRP for those who participated largely appears to be beyond question, resources could have arguably been allocated more wisely. Opening the state's safety net to all categories of migrants is one example for a possible policy, which could have been more fair and productive. It is unfair and ultimately unwise to exclude temporary immigrants from unemployment benefits or self-employed foreigners from participating in the public system of health care, while, at the same time, demanding that they pay taxes. The state should further utilise means to eradicate organised crime and corruption practices associated with migration, and the society as a whole needs to realise that immigrants are a permanent phenomenon. Therefore, once admitted to the country, immigrants should benefit from the same rights and obligations as every domestic worker and citizen. If the state had managed the inflow of immigrants and their legal and social integration into the majority society in a better way, the need would have been avoided to instrumentally dispense of people who had become unemployed and thus superfluous.

Even if the global recession severely depressed the booming Czech economy, I argue that the current disconsolate situation of most recent immigrants in the country has been accentuated and accelerated, rather than caused by the global recession. In other words, the glut on the guest-worker labour market was likely to cause a "burst" of the bubble anyway.

\section{Acknowledgements}

While there were many people who enabled this study, there are two people I would like to thank in particular. Aliaksandr Sudliankou helped me with translations from/ into Russian, Ukrainian and Belarusian. He was also a priceless resource in translating many of the cultural cues that would otherwise not have attracted my attention. For numerous insights into Mongolian culture and practices, I am also indebted 
to Otgonerdene Erdenebat, a student who provides social assistance services to other Mongolians living in the Czech Republic through several non-governmental organisations.

\section{References}

Aranda, Elizabeth 2006: Emotional Bridges to Puerto Rico: Migration, Return Migration, and the Struggles of Incorporation. Lanham: Rowman \& Littlefield Publishers, Inc.

Balaz, Vladimir; Williams, Allan; Kollar, Danie/ 2004: Temporary versus permanent youth brain drain. Economic implications. In: International Migration 42,4: 3-32.

Balderrama, Francisco; Rodriguez, Raymond 2006: Decade of Betrayal. Mexican Repatriation in the 1930s. Albuquerque: University of New Mexico Press.

Baršová, Andrea; Barša, Pave/ 2005: Přistěhovalectví a liberální stát. Brno: Masarykova Univerzita.

Beets, Gijs; Willekens, Frans 2010: The Global Economic Crisis and International Migration: An Uncertain Outlook. Working paper. Vienna Yearbook of Population Research 2009.

Bonacich, Edna 1973: Theory of Middleman Minorities. In: American Sociological Review 38: 583-94.

Borjas, George 1987: Self-Selection and the Earnings of Immigrants. In: American Economic Review. 77,4: 531-53.

Brettell, Caroline 1979: Emigrar para Voltar: A Portugese Ideology of Return Migration. In: Papers in Anthropology 20: 1-20.

Burčíková, Petra 2006: Obchod s lidmi a nucená či vykořistující práce v České republice. Praha: La Strada.

Cassarino, Jean-Pierre 2004: Theorizing Return Migration. The Conceptual Approach to Return Migrants Revisited. In: International Journal on Multicultural Societies 6,2: 253-279.

Castles, Stephen; Miller, Mark 2003: The Age of Migration: International Population Movements in the Modern World. Third Edition. New York/London: The Guilford Press.

Čermáková, Dita 2008: Klientský systém a jeho specifika. In: Drbohlav, Dušan (Eds.): Nelegální ekonomické aktivity migrantů. Cesko v evropském kontextu. Praha: Karolinum.

Černik, Jan 2006: Of Clients and Chereps. The Organizational Structures of Ukrainian Labour Migration. In: Szczepaniaková, Alice; Caněk, Marek; Grill, Jan (Eds.): Migration Processes in Central and Eastern Europe. Unpacking the Diversity. Praha: Multikulturní centrum: 25-29.

Chiswick, Barry 2000: Are Immigrants Favorably Self-Selected? An Economic Analysis. In: Brettell, Caroline; Hollifield, James (Eds.): Migration Theory. New York/London: Routledge.

Czech Statistical Office 2008, 2009, 2010. www.czso.cz.

Drbohlav, Dušan (Eds.) 2008: Nelegální ekonomické aktivity migrantů. Česko v evropském kontextu. Praha: Karolinum. 
Drbohlav, Dušan; Lachmanová, Lenka 2008: Neoprávněné ekonomické aktivity migrantů v Česku - realita očima expertů (Delfy výzkum). In: Drbohlav, Dušan (Eds.) 2008: Nelegální ekonomické aktivity migrantů. Česko v evropském kontextu. Praha: Karolinum.

Drbohlav, Dušan 2004: Migration Trends in Selected EU Applicant Countries. Volume II - The Czech Republic. Vienna: International Organization for Migration.

Ehrenreich, Barbara; Hochschild, Arlie (Eds.) 2004: Global Woman. Nannies, Maids, and Sex Workers in the New Economy. New York: Henry Holt and Company.

Foner, Nancy 2005: In a New Land. A Comparative View of Immigration. New York: New York University Press.

Gmelch, George 1992: Double Passage: The Lives of Caribbean Migrants Abroad and Back Home. Ann Arbor: University of Michigan Press.

Grzymala-Kazlowska, Alexandra 2005: From Ethnic Cooperation to In-Group Competition. Undocumented Polish Workers in Brussels. In: Journal of Ethnic and Migration Studies 31,4: 675-697.

Hnilicová, Helena; Dobiášová, Karolína; Č̌ižiňský, Pavel 2010: Komerční zdravotní pojištění cizinců v ČR. Praha: Multikulturní centrum.

Janeba, Tomáš; Jelinkova, Marie: Preliminary Report on Mongolian Migration to the Czech Republic. Unpublished manuscript.

Krebs, Michal 2010: Stop pracovnímu vykořistování - pohled zblízka. Analýza procesu agenturního zaměstnávání Vietnamců a Vietnamek v ČR. Praha: La Strada.

Kocourek, Jiří 2008: Podmíněnosti současné migrace Vietnamců do Česka. In: Drbohlav, Dušan (Eds.): Nelegální ekonomické activity migrantů. Česko v evropském kontextu. Praha: Karolinum.

Kocourek, Jiří 2006: Vietnamci v ČR. In: Sociologické studie 6, 10. Praha: SOÚ AV ČR.

Komárek, Michal 2009: Zpátky do Hanoje, ňoumové. In: Respekt 7, 9.2.2009: 20-22 [http://respekt.ihned.cz/c1-35745690-zpatky-do-hanoje-noumove, 25.11.2009].

Light, Ivan 1972: Ethnic Entreprise in America. Business and Welfare among Chinese, Japanese, and Blacks. Berkeley: University of California Press.

Lux, Martin; Črermák, Daniel; Obadalová, Miroslava; Sunega, Petr; Vajdová, Zdenka 2002: Bydlení - věc veřejná. Praha: SLON.

Malynovska, Olena 2008: Migrace z Ukrajiny s důrazem na Česko jaǩ cílovou zemi. In: Drbohlav, Dušan (Eds.): Nelegální ekonomické aktivity migrantů. Česko v evropském kontextu. Praha: Karolinum.

Martínková, Šárka 2007: Vietnamské etnikum, jeho sociabilita a sociální sítě v prostředí Prahy. Praha: Etnologický ústav.

Massey, Douglas et al. 1998: World in Motion. Understanding International Migration at the End of the Millennium. Oxford: Oxford University Press.

Ministry of the Interior (Ministerstvo vnitra) 2009: Projekt dobrovolných návratů úspěšně ukončen. [http://www.mvcr.cz/clanek/projekt-dobrovolnych-navratu-uspesne-ukoncen.aspx, 15.1.2010].

Ministry of Labor and Social Affairs (Ministerstvo práce a sociálních věcí) 2009: Souhrná informace za rok 2009 o aktivitách realizovaných př́slušnými resorty, resp. jejich výkonnými složkamiv oblasti potírání nelegálního zaměstnávání cizinců. [http://www. mpsv.cz/files/clanky/9094/informace_2009.pdf, 27.5.2010]. 
Morawska, Ewa 1991: Return Migrations: Theoretical and Reseach Agenda. In: Vecoli, Rudolph; Sinke, Suzanne: Urbana/Chicago: University of Illinois Press.

Mošňjaga, Valerie; Lupták, Milan 2008: Česko v plánech a strategiích moldavských pracovních migrantů. In: Drbohlav, Dušan (Eds.): Nelegální ekonomické aktivity migrantů. Česko v evropském kontextu. Praha: Karolinum.

Nazario, Sonia 2007: Enrique's Journey. Random House Trade Paperbacks.

Ngai, Mae 2005: Impossible Subjects: Illegal Aliens and the Making of Modern America. Princeton University Press.

Nguyen, Thao Minh 2010: Migration, remittances, and economic development. Case of Vietnam. [Http://www.trf.or.th/TRFGallery/Upload/Gallery/Documents/ Files/1000000027.pdf, 18.10.2010].

Nožina, Miroslav 2010: Crime networks in Vietnamese diasporas. The Czech Republic case. In: Crime, Law Soc Change 53: 229-258.

Pai, Hsiao-Hung 2008: Chinese Whispers. London: Penguin Books.

Papademetriou, Demetrios; Terrazas, Aaron 2009: Immigrants and the Current Economic Crisis. Research Evidence, Policy Challenges, and Implications. Working Paper. Washington, DC: Migration Policy Institute.

Pechová, Eva 2007: Migrace z Vietnamu do České republiky v kontextu problematiky obchodu s lidmi a vykořistování. Praha: La Strada.

Pecina, Martin 2009: Dobrovolné návraty - dosavadní výsledky a další vývoj. Presentation. [www.mvcr.cz/soubor/prezentace-dobrovolne-navraty.aspx, 15.1.2009].

Penninx, Rinnus 1986: International Migration in Western Europe Since 1973: Developments, Mechanisms and Controls. In: International Migration Review 20,4.

Poradna pro občanství/Občanská a lidská práva 2007: Připomínky k cizineckému zákonu. Praha: Poradna.

Portes, Alejandro 1999: The Study of Transnationalism: Pitfalls and Promise of an Emergent Research Field. In: Ethnic and Racial Studies 22,2: 217-37.

Portes, Alejandro; Bach, Robert 1985: Latin Journey. Cuban and Mexican Immigrants in the United States. Berkeley: Universtity of California Press.

Rákoczyová, Miroslava; Trbola, Robert; Vyhlídal, Jiř́; Kofroň, Pavel 2007: Zaměstnavatelé zahraničních pracovníků $\vee$ České republice a jejich role $\vee$ procesu sociální integrace: Analýza poptávky po zahraniční pracovní síle. Praha: VÚPSV.

Saková, Tereza; Martínková, Šárka 2009: Role inspektorátů práce při kontrole pracovních agentur v České republice. Praha: Multikulturní centrum.

Stark, Oded; Taylor, J. Edward 1989: Relative deprivation in international migration. In: Demography 26: 1-14.

Sward, Jon 2009: Assisted Voluntary Return (AVR): an Opportunity for Development? Development Research Centre on Migration, Globalisation \& Poverty, Briefing No. 20. September. [http://www.migrationdrc.org/publications/briefing_papers/BP20.pdf].

White, Anne; Ryan, Louise 2008: Polish ,Temporary' Migration. The Formation and Significance of Social Networks. In: Europe-Asia Studies 60,9: 1467-1509.

Wilson, Tamar Diane 2009: Economic crisis and the decline of remittances to Mexico. Social thought and commentary. In: Anthropological Quarterly 82,2: 587-597. 
A German translation of this reviewed and author's authorised original article by the Federal Institute for Population Research is available under the title "Reaktionen unter Zuwanderern in der Tschechischen Republik auf die Wirtschaftskrise: Hinderungs- und Hemmfaktoren für die Rückkehr in die Heimat", DOI 10.4232/10.CPoS-2012-02de or URN urn:nbn:de:bib-cpos-2012-02de4, at http://www.comparativepopulationstudies.de.

Date of submission: 11.01.2011

Date of Acceptance: 19.01.2012

Dr. Marketa Rulikova ( $₫)$. Williams College, MA 01267 USA. E-Mail: Marketa.Rulikova@ williams.edu. URL: http://international.williams.edu 


\section{Comparative Population Studies - Zeitschrift für Bevölkerungswissenschaft}

wWw.comparativepopulationstudies.de

ISSN: 1869-8980 (Print) - 1869-8999 (Internet)

Published by / Herausgegeben von

Prof. Dr. Norbert F. Schneider

Federal Institute for Population Research

D-65180 Wiesbaden / Germany

Managing Editor /

Verantwortlicher Redakteur

Frank Swiaczny

Editorial Assistant /

Redaktionsassistenz

Katrin Schiefer

Language \& Copy Editor (English) /

Lektorat \& Übersetzungen (englisch)

Amelie Franke

Copy Editor (German) /

Lektorat (deutsch)

Dr. Evelyn Grünheid

\section{Layout / Satz}

Beatriz Feiler-Fuchs

E-mail: cpos@destatis.de

\author{
Scientific Advisory Board / \\ Wissenschaftlicher Beirat \\ Jürgen Dorbritz (Wiesbaden) \\ Paul Gans (Mannheim) \\ Johannes Huinink (Bremen) \\ Marc Luy (Wien) \\ Clara H. Mulder (Groningen) \\ Notburga Ott (Bochum) \\ Peter Preisendörfer (Mainz)
}

\section{Board of Reviewers / Gutachterbeirat} Martin Abraham (Erlangen) Laura Bernardi (Lausanne) Hansjörg Bucher (Bonn) Claudia Diehl (Göttingen) Andreas Diekmann (Zürich) Gabriele Doblhammer-Reiter (Rostock) Henriette Engelhardt-Wölfler (Bamberg) E.-Jürgen Flöthmann (Bielefeld) Alexia Fürnkranz-Prskawetz (Wien) Beat Fux (Zürich) Joshua Goldstein (Rostock) Karsten Hank (Köln) Sonja Haug (Regensburg) Franz-Josef Kemper (Berlin) Michaela Kreyenfeld (Rostock) Aart C. Liefbroer (Den Haag) Kurt Lüscher (Konstanz) Dimiter Philipov (Wien) Tomáš Sobotka (Wien) Heike Trappe (Rostock) 